\title{
FINTECH INDUSTRY IN UKRAINE: PROBLEMS AND PROSPECTS FOR THE IMPLEMENTATION OF INNOVATIVE SOLUTIONS
}

\author{
Vira Vartsaba ${ }^{1}$, Olha Zaslavska ${ }^{2}$
}

\begin{abstract}
The article considers the issues of development of the financial technology market, its opportunities and obstacles, as well as the need and inevitability of the introduction of fintech solutions in the financial and credit spheres. The main purpose of the research is to determine the role of fintech services in the state economy, the prospects for their development, as well as to substantiate the trends of adaptation of classical credit institutions and consumers of financial services to new financial technologies at different stages of their development. Systematization of literature sources and approaches to solving the problem of intensifying activities in the field of innovative finance has shown that fintech is a specific cross-sectoral industry, which lies on the border of financial and IT spheres, consists of companies that use technology to improve the efficiency of financial services and encompasses digital innovations and programs that facilitate the creation and implementation of financial products. The urgency of solving this scientific problem is that the market of financial technologies is one of the fastest growing. That is why it highlights the need for traditional financial institutions to digitize their activities through a radical change in the business model in order to strengthen competitive positions and provide strategic advantages. The research of the implementation of financial technologies in the article is carried out in the following logical sequence: systematization of stages of development of the fintech industry; assessment of the development of the fintech sphere in Ukraine in the context of the transition to the stage of integration with the banking system; study of the strengths and weaknesses of domestic banks and fintech companies, outlining obstacles and necessary changes for further digitization of the financial and credit system; research of the process of implementation of fintech services on the example of the technology life cycle model; assessment of the relationship between the level of financial and digital literacy of the population and the depth of promotion of innovative fintech products; identifying ways to increase the financial and digital inclusion of the population of Ukraine. Methods of the empirical, experimental and theoretical levels became the methodological tools of the conducted research. The results were evaluated and analyzed on the basis of surveys conducted in 2017-2019 by the Ukrainian Association of Fintech and Innovative Companies, the Ministry of Digital Transformation of Ukraine, the Ukrainian division of the British audit and consulting company Ernst \& Young, and the US Agency for International Development. The article presents the results of an empirical analysis of the relations and interdependence of classical and innovative financial institutions, which showed the inevitability of the processes of digitization of financial services. The study empirically confirms and theoretically proves that the favorable development of the fintech industry is based on the following: the level of public awareness in the field of finance and information technology; the level of innovative development of financial institutions and the degree of penetration of the fintech companies in the financial market of the country; completeness of the legal framework.
\end{abstract}

Key words: market of innovative technologies, fintech, fintech services, digitization, technology adoption lifecycle, financial literacy, digital literacy, financial in-clusion.

JEL Classification: G21, G29, G53, O33

\footnotetext{
Corresponding author:

${ }^{1}$ Uzhhorod National University, Ukraine.

E-mail: vira.vartsaba@gmail.com

ORCID: https://orcid.org/0000-0001-8693-8726

ResearcherID: https://publons.com/researcher/AAQ-8840-2020

${ }^{2}$ Uzhhorod National University, Ukraine.

E-mail: o.i.zaslavska@gmail.com

ORCID: https://orcid.org/0000-0002-6418-9514

ResearcherID: https://publons.com/researcher/F-6924-2019
} 


\section{Introduction}

Digital technology is an integral part of modern life and the financial market is no exception. Over the past twenty years, the world has seen a rapid rise in the development of new models of financial services, including in the sectors of consumer banking and payments, insurance, asset management and more. The need for the development of non-physical service channels, implementation of operational solutions and development of new methods of establishing contacts with potential customers, attracting new and retaining existing clients, is becoming urgent.

The market of financial technologies is one of the fastest growing; it occupies a leading position in the dynamics of its development both in financial terms and in terms of end-user coverage. The revolution in the field of finance is caused by new waves of high-tech startups that work better, faster and cheaper in the areas of lend-ing, payments, capital management compared to traditional banks. The development of the fintech sector promotes the emergence of new financial products that provide more opportunities and convenience for users and require the introduction of new models of functioning and interaction of all participants in financial relations.

The aim of the article is to determine the role of fintech services in the state economy, the prospects for their development, as well as to substantiate the trends of adaptation of classical credit institutions and consumers of financial services to new financial technologies at different stages of their development.

Nowadays, the collaboration of banks and IT-sphere is a key condition for further effective development of the credit system. Digital technologies give the modern economy new essential features, such as open communications, cooperation and constant updating. This highlights the need for traditional financial institutions to digitize their activities through a radical change in the business model in order to strengthen competitive positions and provide strategic advantages.

The research was conducted at the empirical and theoretical levels. In particu-lar, at the empirical level, the main function was the descriptive characterization of phenomena, and its result was a set of scientific facts and empirical generalizations. In turn, at the theoretical level, the task of revealing the essential causes and connec-tions between phenomena and their rational cognition prevailed.

In order to conduct the main part of the research, we have put forward the fol-lowing initial hypotheses:

H1. The speed of distribution and implementation of fintech services depends on the level of financial and technical literacy of consumers and their perception of innovation.

$\mathrm{H} 2$. The speed of distribution and implementation of fintech services depends on the level of development of the state's financial system and HR potential.
In our opinion, an important feature of different scientific researches is their versatility, i.e. the ability to solve problems by different methods and ways. Therefore, the development of hypotheses, their refutation or proof is based on a system of methods and approaches to the study of phenomena and patterns of nature, society and thinking.

In order to study the development of financial technologies, we used the historical method of cognition. This method made it possible to study the formation of the fintech industry in chronological order. In addition, the systematization of the stages of fintech development is based on the analysis and synthesis of the essential features of this system. Since the methods of analysis and synthesis are interconnected and embody the unity of opposites, we used such types as: direct method - in order to identify individual stages of development of financial technologies; elemental and theoretical method - for selection of causal relations between stages; structural and genetic method - in order to identify the main factors that have created a decisive influence on the formation of the modern sphere of fi-nancial technologies.

The article assesses the development of the fintech sector in Ukraine, focusing on cooperation and future integration with the banking system. The dialectical and materialist method of cognition was used in this study. In particular, it showed the connection, and interdependence of classical and innovative financial institutions. In the same context, the method of comparison was used to identify differences and characteristics of the Ukrainian fintech companies and banks.

The above techniques belong to the methods of the empirical level, which are used at the stage of formation of a scientific hypothesis.

Another group of methods are techniques of experimental and theoretical level. They help to identify certain reliable facts, carry out their accumulation and cross-check. This group includes methods of induction and deduction. Thus, the inductive method of research made it possible to establish general principles for the existence of all phenomena of a particular area on individual facts. During the deduction, a final conclusion was drawn from several initial statements based on certain patterns. In particular, these methods were used to study the life cycle curve of innovation (in their general sense) and its use in order to implement in the field of financial technology; as well as identifying barriers to the spread of fintech services among potential users. Thus, induction made it possible to prepare the ground for deduction and provide knowledge of factual material, and deduction, in turn, allowed expanding the scope of this knowledge.

The article also uses descriptive research methods, which include question-naires, surveys and recording of results, in particular, the attitude of the population to 
the introduction of fintech innovations in everyday life, as well as the state of banks and fintech companies in the context of their cooperation and vision of financial technology industry in Ukraine. The results were evaluated and analyzed based on the surveys conducted by the Ukrainian Association of Fintech and Innovative Companies (Ukrainian Association of Fintech and Innovative Companies, 2019), the Ministry of Digital Transformation of Ukraine (Ministry of Digital Transformation of Ukraine, 2019), the Ukrainian division of the British audit and consulting company Ernst \& Young (Ernst \& Young, 2019), and the US Agency for International Development (USAID, 2019).

\section{Literature review}

A significant contribution to the study of the features of implementation of fintech solutions in financial and banking systems was made by foreign scholars, including: P. Schueffel (Schueffel, 2016), G. Dorfleitner, L. Hornuf, M. Schmitt and M. Weber (Dorfleitner et al., 2016), K. Leong and A. Sang (Leong and Sang, 2018), R. Teigland, C. Ingram, K, Kallstrand and N. Wesley-James (Teigland et al., 2015), N. Morozko and V. Didenko (Morozko and Didenko, 2017), S. Chishti and J. Barberis (Chishti and Barberis, 2016).

The issues of the emergence and functioning of the financial technology industry are reflected in the works of such Ukrainian scientists as: A. Mazaraki and S. Volosovych (Mazaraki and Volosovych, 2018), V. Mishchenko (Mishchenko et al., 2018), M. Tarasyuk and O. Koshcheev (Tarasyuk and Koshcheev, 2017), L. Dudynets (Dudynets, 2018), M. Dyba and Ye. Osadchyy (Dyba and Osadchyy, 2018), H. Pochenchuk (Pochenchuk, 2018).

Thorough researches in the fintech industry is carried out by the International Institute for Management Development (IIMD, 2019), the International Association of Insurance Supervisors (Kawai, 2016), Ernst \& Young (Ernst \& Young, 2019), Deloitte (Deloitte, 2017), the United States Agency for International Development (USAID, 2019), etc.

Financial technology or fintech is a symbiosis of finance and new technologies using mobile applications and algorithms. The concept of "fintech" is not new, but only in recent years, this kind of business has begun to acquire the features of a separate industry. At the same time, financial technologies are changing extremely rapidly under the influence of different social needs, what causes an ambiguity in the understanding of this concept. Currently, there is no generally accepted interpretation of the term "fintech".

The International Association of Insurance Supervisors, represented by its Secretary General Y. Kawai (Kawai, 2016), provides the following definition: fintech can be described as technologically enabled financial innovation, that is giving rise to new business models, applications, processes and products, which can have a material effect on financial markets, institutions and the provision of financial services.

Another approach to the interpretation of this concept is demonstrated by the Board of Governors of the US Federal Reserve System (US Federal Reserve, 2016). According to their opinion, fintech is an industry composed of companies that use technology to make financial systems and the delivery of financial services more ef-ficient.

German scientists, authors of the report "The FinTech Market in Germany” (Dorfleitner et al., 2016) believe that it is impossible to define the term "fintech" from a legislative point of view. Fintech companies are subject to differing kinds of legal and regulatory obligations due to their highly various business models and the extremely diverse products and services they offer. In a general sense, fintech en-compasses companies that simply provide the technology and software solutions to financial service providers.

In order to generalize the understanding of fintech, British scientists K. Leong and A. Sung (Leong and Sung, 2018) define it as a cross-disciplinary subject that combines finance, technology management and innovation management. According to them, financial technologies are any innovative ideas that improve financial ser-vice processes by proposing technology solutions according to different business sit-uations, while the ideas could also lead to new business models.

R. Teigland (Teigland et al., 2015), a researcher at the Stockholm School of Economics, believes that fintech is a rather complex category to define. Based on the name, it is a space where technology is used in the financial industry. This definition is very broad and encompasses the entire finance industry since every area uses technology in some way: from SWIFT as the basis of the global digital transfer system to retail banks operating digital portals to stock exchanges and clearinghouses.

Russian scholars N. Morozko and V. Didenko (Morozko and Didenko, 2017) believe that financial technology space is an industry that includes technologies for banking and corporate finance, capital markets, financial analytics, payments, personal management finance, private and venture capital.

According to the Ukrainian scientists A. Mazaraki and S. Volosovych (Mazaraki and Volosovych, 2018), in the general sense, fintech is an innovative technology used by financial institutions, government agencies, trade organizations to meet the needs of consumers of financial, administrative services and goods in conditions of development of the consumer economy.

Thus, the term "fintech" is used to describe a wide range of innovations in the financial sector. An analysis of the scientific literature allows us to conclude that several approaches should be applied to the interpretation of this concept. 
Firstly, fintech is a branch of the economy that consists of companies (mostly startups) that use technology to provide financial services more efficiently.

Secondly, fintech is a set of institutions that implement innovative business models and technologies for expansion and distribution of financial services.

Thirdly, fintech can be defined as computer programs, applications, and other technologies used to support or provide banking and financial services.

And, fourthly, fintech is a service provided by technology companies using special software and focused on the financial needs of customers.

Thus, in our opinion, fintech is a specific cross-sectoral industry, which lies on the border of financial and IT spheres, consists of companies that use technology to improve the efficiency of financial services and encompasses digital innovations and programs that facilitate the creation and implementation of financial products.

\section{Stages of development of the fintech industry}

Financial technology (fintech) is a relatively new industry. According to vari-ous estimates, there are more than 20000 fintech startups in the world, 40\% of which appeared in 2019. This area is the most dynamic in terms of development speed. In particular, fintech investments amounted to 111 billion USD in 2019 (Statista, 2020). The increasing popularity of financial technologies and the number of fintech startups are due to the fact that they are a cheaper alternative to banks in the financial market.

The development of financial technologies has been particularly noticeable over the last ten years. The key factors are the following:

- the loss of customer confidence in the traditional banking sector during the global financial crisis of 2008 2009;

- the growing expectations of society for the provided services, including financial ones. Nowadays consumers are focused on continuous updating and speeding up of processes, higher availability of technology and convenience of services;

- the spread of mobile Internet and social networks. This leads to the fact that the focus of the strategy of attracting bank customers is shifting from the expansion of the branch network to the creation of online services; - the desire for innovations, the increased requirements for the ease of use of services, the quality and speed of information acquisition which are the features of the largest generation - the millennials (born between 1980 and 2000);

- the success of technology companies in other sectors of the economy (trade in goods, entertainment industry, etc.).

The first stage in the evolution of the fintech-industry is closely related to the development of infrastructure and the emergence of the first technological solutions. At the beginning of its history, this field remained analogous for a long time. It means that all transceivers used signals that could be transmitted by cable or radio. Therefore, this period is associated with the creation of the telegraph in 1816, which allowed the transmission of text information over a considerable distance and defined the whole era of financial technology. One of the first users to introduce such communications were the brokerage offices, which made it possible to accelerate the transfer of data between commodity and stock exchanges in different cities and to increase the liquidity of trading (Ferderer, 2008).

The next stage is characterized by the creation and implementation of the first computers. In the late 1960s, the development of computer technology gave an impetus to the transformation of the financial sector from analogue to digital industry. In particular, the first electronic payment systems appeared, and the rapid growth in the volume of financial transactions between counterparties of different countries became the driver of the creation of a Society for Worldwide Interbank Financial Telecommunications (SWIFT). In 1967, the British bank Barclays established the first ATM to provide access to liquidity during off-hours. With the development of the Internet technologies in the early 1990s, many large financial institutions began to advertise their products online. In 1995, an American multinational financial services company Wells Fargo added the ability to manage and order online banking services to its site. Later its example was followed by other financial intermediaries (Trunin et al., 2019).

The beginning of the new millennium (2000-2010) can be characterized as the next stage in the evolution of financial technologies. The starting point of a new era of development were two crises at the beginning of the 21st century: the crisis of the dotcoms (the companies whose business models are fully based on the Internet), and the global financial crisis of 2008-2009. The latter, in particular, has undermined the credibility of traditional financial institutions, which suffered severe restrictive measures by regulators. This was the beginning of a new stage in the development of financial technologies, characterized by the emergence of a significant number of startup companies (Arner et al., 2015).

The fourth stage of the development of the fintech industry was in the last decade: 2010-2020. For this period, it was typical to provide financial products and services to individuals and legal entities directly by startups. The introduction of innovative financial technologies led to the formation of a fundamentally new model of banking business, which is accompanied by intensification of the processes of replacement of banking offices by computer programs. During this period, bank-funded innovation centers began to emerge. Gradually, the fintech products began to move from a category of products focused on a narrow 
circle of technologically competent customers to society as a whole.

In the future, the fintech industry will have two more stages: partnership with the creditsystem andintegration. In the coming years, there will be a transition from competition to partnership between classic banking institutions and fintech companies. Such a development strategy will allow both of them to cooperate mutually. Banks with many years of experience and positive image enjoy loyalty among customers, but they do not always have time to implement the latest technologies. On the other hand, fintech startups have useful services and products that are difficult for newcomers to promote in the market. One of the major collaboration platforms is Open Banking. It refers to banks opening up their application programming interfaces to third party providers (TPPs), so that the TPPs and fintech providers have access to their data and, based on that, can build new applications and services or create new services together with financial institutions. Based on this open data, startups can create new solutions for banking customers.

The final period - the integration phase - foresees that open marketplaces, API (application programming interface) and complex analytics will emerge in the future. All this will result in the final merger of credit institutions and fintech com-panies.

\section{Cooperation between banks and fintech companies}

In this context, it is important to assess the development of the fintech sphere in Ukraine, focusing on cooperation and future integration with the banking system. First of all, it should be noted that more than 70 new fintech companies have appeared in the domestic market during 2019, representing almost $40 \%$ of their total. In general, at the beginning of 2020 , there were 180 entities in the fintech industry in Ukraine that is 2.5 times the number of existing banks.

Figure 1 presents the survey results of the most technological banks in Ukraine regarding their partnership with the fintech system.

Among the surveyed Ukrainian banks, 73\% of institutions have joint projects with fintech companies, which is much simpler and cheaper than maintaining their own teams of software developers. The same number of banks has their own innovation centers. At the same time, most institutions do not have platforms for incubation and acceleration of fintech projects. Many of such projects are implemented with the help of fintech companies, which enables banks to reduce investment costs and minimize risks. Financing is still a pain point for fintech companies. As we can see, 100\% of the studied banking institutions do not invest in fintech companies. Usually, new technological projects in the world are funded by outside capital and, above all, by banking resources. However, in Ukraine, 61\% of fintech companies are fully funded from their own sources.

In our opinion, banks and fintech companies are interested in a mutually beneficial partnership, as each has its own strengths and weaknesses. Banks have significant amounts of financial resources and a customer base. But not all of them are willing to invest their own financial, time and human resources in developing innovative products. In addition, the activities of banks are tightly regulated by the central bank. Therefore, they may not always be able to adapt quickly to the growing needs of customers, as this requires an appropriate regulatory framework.

The strength of fintech companies is the high level of qualification and innovative potential of employees. In addition, they have much more information about their potential customers' needs by tracking their activity on social networks, and navigating through geolocation applications. The disadvantage of fintech

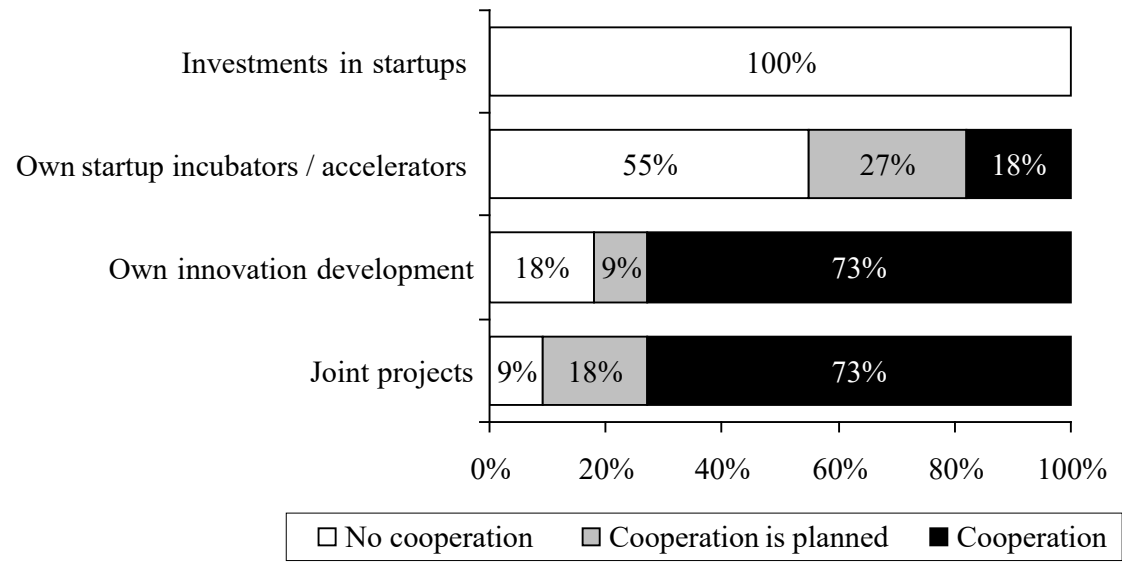

Figure 1. Involvement of the Ukrainian banks in cooperation with fintech companies

Source: built by authors based on (Ukrainian Association of Fintech and Innovative Companies, 2019) 
Table 1

Rating of key aspects of the fintech industry development in Ukraine

\begin{tabular}{|l|l|l|}
\hline \multicolumn{2}{|c|}{ IMPLEMENTATION OF NON-REPRESENTED OR UNDERREPRESENTED FINTECH SERVICES } \\
\hline $1 N$ & \multicolumn{1}{|c|}{ In terms of fintech companies } & \multicolumn{1}{c|}{ In terms of banks } \\
\hline 1 & $\begin{array}{l}\text { Cross-border payments for individuals and small and medium- } \\
\text { sized businesses }\end{array}$ & Online payments directly from a bank account \\
\hline 2 & $\begin{array}{l}\text { Providing digital financial services to individuals who do not have } \\
\text { traditional bank accounts }\end{array}$ & $\begin{array}{l}\text { Providing digital financial services to individuals who do not have } \\
\text { traditional bank accounts }\end{array}$ \\
\hline 3 & Electronic invoicing & Online shopping lending \\
\hline \multicolumn{2}{|c|}{ LEGISLATIVE REVIEWS REQUIRED FOR FINTECH INDUSTRY DEVELOPMENT } \\
\hline 1 & Outdated and unfavorable legislation & Remote customer identification \\
\hline 3 & Partnership problems with classic credit institutions & The cost of digital transformation \\
\hline 3 & Low level of financial literacy of the population & Digital payments from government agencies and in their favor \\
\hline 1 & Remote customer identification & P2P lending regulation \\
\hline 2 & Electronic money & $\begin{array}{l}\text { Licensing AIS (account information services) and PIS (payment } \\
\text { initiation services) }\end{array}$ \\
\hline
\end{tabular}

Source: built by authors based on (USAID, 2019)

companies is that they mainly specialize in a narrow range of operations. Besides they do not always have enough funding to implement their ideas, as well as the time needed to win customers' trust. Therefore, both for banks and for fintech companies, the smartest strategy is not to compete, but to look for mutually beneficial ways of partnership (Financial Pulse, n.d.).

The options for cooperation between banks and fintech companies can vary from simple use of the services of fintech providers to a full-fledged partnership, investments in the implementation of new systems or the acquisition of implemented projects. In particular, priority areas for cooperation are digital banking, electronic payments, car and travel insurance, $\mathrm{P} 2 \mathrm{P}$ lending and B2P lending.

Table 1 presents the perspectives for the development of the fintech industry in Ukraine, the main barriers and the necessary legislative changes in terms of banks and fintech companies.

The above-mentioned rating highlights the obvious differences between the moods of fintech providers and banks. This is due to the fact that only $57 \%$ of all domestic fintech companies operate exclusively in Ukraine. Moreover, more than $70 \%$ of them plan to enter foreign markets. The reason for this is a weak domestic market with low demand and disposable income within the country [catalog]. That is why a considerable number of companies are influenced by global trends of market changes, which are not felt so strongly in Ukraine. However, both fintech companies and banks emphasize the need for remote identification of customers, in particular, banks. Therefore, they believe that availability of a legal framework for remote customer identification is a necessary factor in the development of the industry. In general, the problem of outdated and unfavorable legislation is a key issue for both groups of institutions. It is also worth noting that fintech companies and banks see significant potential in future of the financial services for individuals who do not have bank accounts. This niche is considered potentially profitable for startups as well as classic credit institutions (USAID, 2019). However, the biggest problem in Ukraine in this area is the low levels of financial inclusivity and literacy of the population, as well as the rejection of the latest technologies by elders.

According to a study by the United States Agency for International Development (USAID), which took into account the level of financial knowledge, behavior and attitude, the overall index of financial literacy of the Ukrainians was $55 \%$. This is the lowest rate among the 30 countries of the Organization for Economic Co-operation and Development (OECD). By the way, the average index among OECD countries is $63 \%$ (USAID, 2019).

\section{Lifecycle curve of innovation adoption}

One of the most topical issues in the activities of fintech companies is the spread of innovations among potential users. This problem was started in the 1960s. In particular, the American scientist Everett Rogers developed a theory of innovation diffusion that explains how, why, and at what speed new ideas and technologies are distributed to different consumer groups (Rogers, 2003). In 1992, this theory was developed by Geoffrey Moore, an American organizational theorist, management consultant and author, known for his work "Crossing the Chasm: Marketing and Selling High-Tech Products to Mainstream Customers” (Moore, 2014). G. Moore's theory is called the technology adoption lifecycle, which is based on the division of consumers into five categories. The highlighted approach is still being taken as a basis for promoting innovative solutions, and in the fintech industry as well. From 


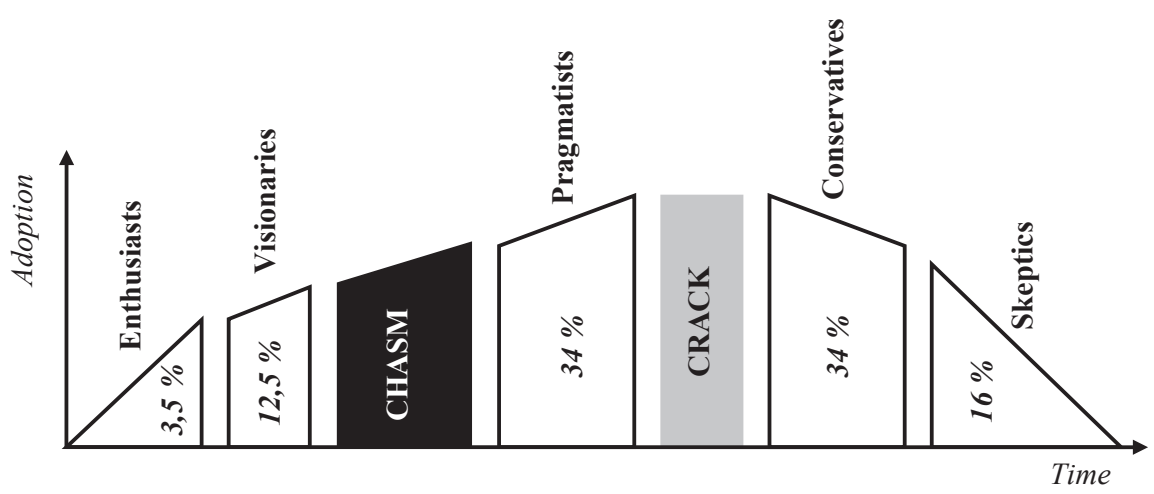

Figure 2. Lifecycle curve of innovation adoption

Source: built by authors based on (Moore, 2014)

this point of view, we believe that this approach quite logically describes the stages of promotion of innovative solutions in the fintech industry (Figure 2).

There are two types of innovations: discontinuous, which require society to change habits, and continuous, which upgrade products but does not change the usual course of action. In the study of the Global FinTech Adoption Index 2019, it is proposed to distinguish two types of fintech services: transformed and invented. Thus, in order to provide the first type of services, which are traditionally offered by classic financial institutions, fintech providers use technology to transform these services, offering consumers a more attractive ones (extended capabilities, greater efficiency, lower rates, etc.). Invented services have not existed before, but they have become possible due to technology (P2P-lending, e-wallets, mobile payments, etc.) (Ernst \& Young, 2019).

The chasm theory concerns discontinuous innovations and invented services. Fintech providers have to fight the inertia of potential buyers to convince the majority to change their usual way of life. As we can see, society's acceptance of technological innovations takes time. Due to different attitudes to innovation, this process takes place in stages, moving from one category of consumers to another.

Therefore, the first to accept new products are technical enthusiasts or innova-tors for whom fintech is a hobby or part of doing business. Later, visionaries or early adopters join, who are interested in the competitive advantages of an innovative product. Consumers of the first two groups form a small primary market, the audience of which is up to $16 \%$ of all potential customers. If a product or service proves its effectiveness, enthusiasts and visionaries are joined by pragmatists ("the early majority"), who make up approximately a third of the market. Unlike previous categories of consumers, they do not seek significant changes, but need stable benefits of an innovative product. For fintech companies, pragmatists are able to become extremely loyal customers. So by enlisting their support, fintech providers gain access to long-term market dominance.

The fourth group - conservatives or "the late majority" - is similar in market coverage to the previous one, but consumers in this segment are suspicious of high technology. They prefer simple and high-quality goods and services, so they are pes-simistic about the benefits that technology will bring them. Eventually, conservatives bring fintech products to their lives because they realize that technological innovations are becoming an integral part of life and business and can pass them by.

The last group of consumers is skeptics, who occupy a small market segment that is resistant to the influence of new technologies. Fintech companies often do not take this category into account as customers; on the other hand, they are the biggest critics of innovations and can answer why the product does not meet their expectations (Moore, 2014).

The gap that exists between visionaries and pragmatists is due to innovations that require significant behavioral changes from the consumer. Such products and services fall into the so-called "chasm" that separates the early and main markets. Pragmatists seek consistency and productivity, but try to avoid global innovations. Therefore, the gap arises when an innovative product, from their point of view, can-not be used as something significantly useful that expands opportunities and simpli-fies life, but is positioned only as a fundamentally new and high-tech product. As a result, the chasm may lead to a refusal to adopt the technology at all.

Another obstacle may be the crack between pragmatists and conservatives. It arises primarily due to insufficient technical and financial literacy of the latter. There-fore, when a product reaches the highest point of development on the market, its application should be as simple as possible so that it continues to be successful among less competent consumers of fintech services. Otherwise, the transition to conservatives may not happen at all (Moore, 2014).

In this context, it is necessary to consider the attitude to innovation of the Ukrainian society through the 


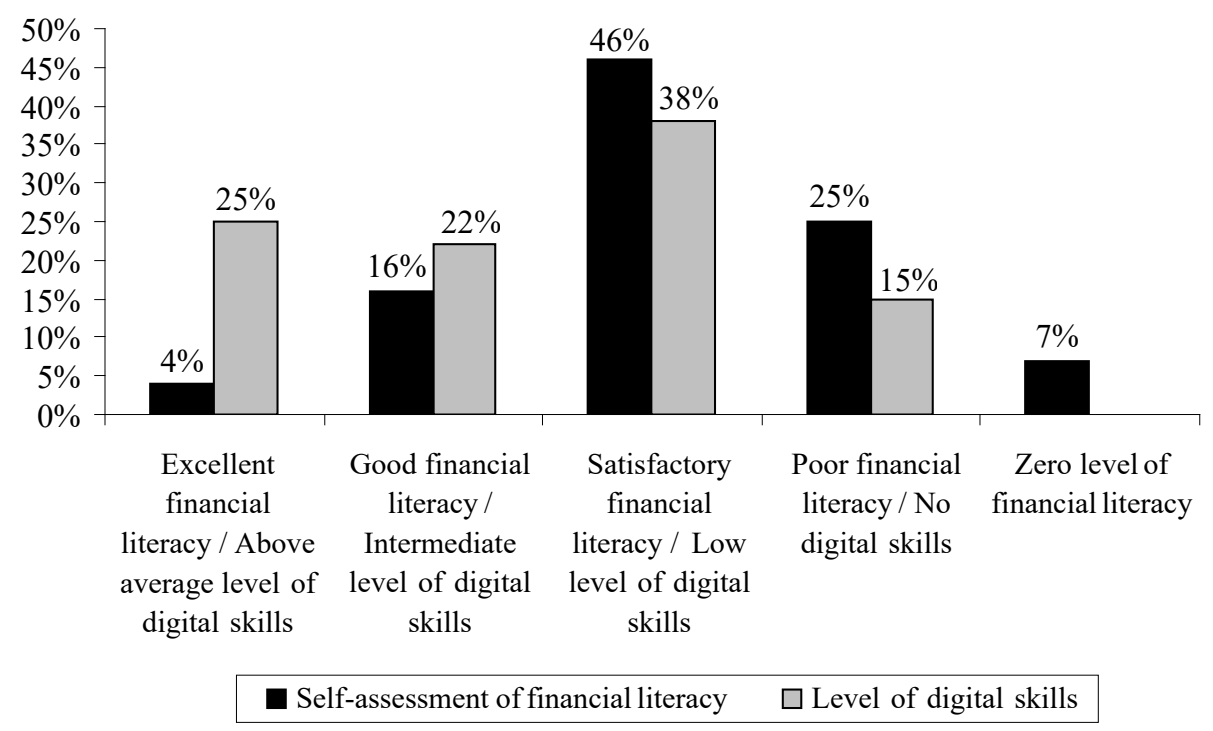

Figure 3. The level of financial and digital literacy of the population of Ukraine

Source: built by authors based on (USAID, 2019; Ministry of Digital Transformation of Ukraine, 2019)

prism of the general level of financial and digital literacy of different groups (Figure 3).

As you can see, the diagram in Figure 3 is similar to the curve of the life cycle of innovation (Figure 2). This confirms the relation between the level of financial and digital literacy and the depth of promotion of innovative fintech products among users.

According to the results of the research, the vast majority of the Ukrainians have only basic knowledge and skills in the financial field and information technology, which allows them to use the simplest services, including payments and settlements. Domestic users do not feel comfortable interacting with financial institutions and are only interested in issues that are of personal importance.

The greatest influence on financial behavior in Ukraine has age and property status of the population. In particular, young people aged 18-34 feel most free in the world of finance and latest technologies. It is important for this group of consumers to be able to obtain reliable information about a financial institution or service in the mode of instant access. Young people will be glad to use any personal financial management tools, if only there was an application for modern gadgets and platforms. Middle-aged Ukrainians are the most experienced users of financial services; they are a socially active category and are used to overcome various difficulties. They are the target audience for the promotion of financial products aimed at long-term planning. As for the older generation, the online space causes them fear. The life experience of consumers in this group has taught them not to trust financial institutions, and being among the victims of Internet frauds increases this distrust and leads to the rejection of even the simplest digital services (USAID, 2019).
In addition, Ukraine is currently experiencing infrastructural unpreparedness to improve the digital skills of the population. The most noticeable is the disparity between cities and villages, which is expressed in unequal access to financial and telecommunications services.

Thus, the study proves that a favorable environment for the development of the financial sector of any country is largely based on four main components:

1) level of public awareness in the field of finance and information technology, as well as their trust in financial institutions;

2) level of development of financial and credit institutions, their innovativity and qualifications of employees and managers;

3) level of development of fintech companies and the degree of their penetration into the financial market of the country;

4) completeness of the legislative, regulatory and supervisory framework.

\section{Conclusions}

Sustainable development of the state and society is the development at the crossing of economic, social and technological efficiency. Financial technologies are a key tool for sustainable development, as they are able not only to increase the efficiency of the financial sector, but also to contribute to the implementation of the strategy of comprehensive development of the state.

In our opinion, the hypotheses put forward at the beginning cannot be refuted or confirmed separately. The study found that the speed of distribution and implementation of fintech services in Ukraine is influenced by many factors, it depends on the level of development of 
the country in a range of aspects such as: financial and digital literacy, innovativity of financial institutions, preparedness of financial markets and communication technologies to promote fintech services and the availability of appropriate legal framework.

Considering the conducted research and in order to achieve the goal of developing the fintech industry in Ukraine and increase financial and digital inclusion of the population, the main ways to overcome existing barriers are the following:

- adaptation of communication strategy and digitization to the socio-demographic structure of the population of Ukraine. In particular, if the focus is mainly on online information channels, the level of accessibility to older groups and people living in rural and mountainous areas is reduced. Therefore, it is necessary to actively involve offline channels (television, screens in social institutions and transport) to broadcast short videos about the essence and benefits of fintech ser-vices for ordinary citizens;

- improvement of the quality of technical support of government agencies. Often, institutions of social, educational, medical, cultural spheres are the drivers of digital change and habits of society. That is why a sufficient level of hardware and software of such institutions is important;

- permanent and systematic formation of demand for digital skills among the population. The message should focus on convenience, time savings, and ease of use of the latest technologies in the financial sector, as well as the inevitability of the transition of most processes to the virtual space and automation of various services; - creation of a platform for digital skills training and its advertising support. Such training platforms should be simple, clear, secure and based on intuitive use. Un-der such conditions, the potential consumer will not only be able to learn how to use online services, but also receive information about the product, its safety and ease of use.

As a result, we should note that the effectiveness of the policy of improvement the level of financial literacy and digital skills of the population depends on the integrated implementation of various learning mechanisms. Therefore, in order to deepen existing knowledge, emphasis should be placed on online learning. When developing basic skills, offline support at the place of residence is the main one. At the same time, the infrastructural resource here can be libraries, clubs, educational institutions, local governments, social protection institutions, pension funds, etc.

Nowadays the importance of this issue has come to the fore, as the COVID-19 pandemic forced the world to move into the virtual reality of communication, education, financial services, health care and more. The current situation makes it clear that there is a need to accelerate as much as possible all the processes that will contribute to the development of the fintech industry. Unprecedented conditions in all areas of activity have shown that in the forefront now there are the businesses that have been the first ones to move into the digital space.

Taking into account the study, we can note the trend towards the development of virtual customer service channels, implementation of operational solutions and the development of new methods of establishing contacts with potential consumers of financial services. This phenomenon also characterizes the Ukrainian financial system, which leads to the regular implementation of new solutions in the areas of innovation and the development of strategies to overcome obstacles along the way. In general, under the condition of qualitative and quantitative development, the fintech industry in Ukraine is able to radically change the existing organizational and institutional structure of the financial and credit system in the future.

In conclusion, it should be noted that the stabilization of the economy, updating the legal framework and implementation of new technologies in the activities of traditional credit institutions can have a beneficial effect on the rapid growth of financial technology, which already surpasses any other high-tech industry in Ukraine.

\section{References:}

Ancri, C. (2016). Fintech Innovation: An Overview. Board of Governors of the Federal Reserve System. Available at: http://pubdocs.worldbank.org/en/767751477065124612/11-Fintech.pdf

Arner, D. W., Barberis, J. N., \& Buckley, R. P. (2015). The Evolution of Fintech: A New Post-Crisis Paradigm? University of Hong Kong Faculty of Law Research Paper, 2015/047. Available at: https://ssrn.com/ abstract=2676553; http://dx.doi.org/10.2139/ssrn.2676553

Center for Economic Research and Forecasting "Financial Pulse". (n.d.) Banks and fintech companies: strength - in unity. Available at: http://finpuls.com/upload/docs/news/banking/reviews/Банки\%20та\%20фінтех-компанії.pdf Chishti, S., \& Barberis, J. (2016). The Fintech Book: The Financial Technology Handbook for Investors, Entrepreneurs and Visionaries. John Wiley \& Sons.

Dorfleitner, G., \& Hornuf, L. \&, Schmitt, M., \& Weber, M. (2016). The Fintech Market in Germany. Available at: https://ssrn.com/abstract=2885931; doi: http://dx.doi.org/10.2139/ssrn.2885931

Dudynets, L.A. (2018). Rozvytok finansovykh tekhnolohiy yak faktor modernizatsiyi finansovoyi systemy [Development of financial technologies as a factor of modernization of the financial system]. Hlobalni ta natsionalni problemy ekonomiky - Global and national problems of economy, vol. 22, pp. 794-798. Available at: http://global-national.in.ua/archive/22-2018/149.pdf. 
Dyba, M. I., \& Osadchyy Ye. S. (2018). Finansovi innovatsiyni instrumenty u bankivskiy systemi [Financial innovative instruments in the banking system]. Stratehiya ekonomichnoho rozvytku Ukrayiny - Strategy of economic development of Ukraine, vol. 42, pp. 99-111. Available at: http://nbuv.gov.ua/UJRN/seru_2018_42_11

Ernst \& Young Global Limited (2019). Global FinTech Adoption Index - 2019. Available at: https://fintechauscensus.ey.com/2019/Documents/ey-global-fintech-adoption-index-2019.pdf

Ferderer, J. P. (2008). Advances in Communication Technology and Growth of the American Over-the-Counter Markets, 1876-1929. The Journal of Economic History, 68/2, 201-534. Available at: https://pdfs.semanticscholar.org/ $3 \mathrm{acb} / 001527508 \mathrm{fd} 3 \mathrm{a} 3 \mathrm{c} 923359 f 04 a 5 c 30 \mathrm{a11b362}$.pdf? ga $=2.209070928 .356871467 .1591345830-1319603959$. 1590922310; doi: https://doi.org/10.1017/S0022050708000387

Kawai, Y. (2016). Fintech and the IAIS. IAIS Newsletter. Available at: https://www.iaisweb.org/file/61139/ iais-newsletter-june-2016-final\%20

Leong, K., \& Sung, A. (2018). FinTech (Financial Technology): What is It and How to Use Technologies to Create Business Value in Fintech Way? International Journal of Innovation, Management and Technology, vol. 9/2, pp. 74-78. Available at: http://www.ijimt.org/vol9/791-M775.pdf; doi: https://doi.org/10.18178/ijimt.2018.9.2.791

Mazaraki, A., \& Volosovych, S. (2018). Fintech u systemi suspilnykh transformatsiy [Fintech in the system of social transformations]. Visnyk Kyyivskoho natsionalnoho torhovelno-ekonomichnoho universytetu - Bulletin of Kyiv National University of Trade and Economics, vol. 2, pp. 5-18. Available at: http://nbuv.gov.ua/UJRN/Vknteu_2018_2_2

Middle East and Central Asia Department, IMF (2017). Fintech: unleashing regional potential of MENAAP and CCA. Available at: https://www.imf.org/ /media/Files/Publications/REO/MCD-CCA/2017/October/ CCAnovember1/Russian/chapter-5-final-rus-oct-20.ashx?la=ru

Ministry of Digital Transformation of Ukraine (2019). Digital literacy of the population of Ukraine. Available at: https://osvita.diia.gov.ua/uploads/0/585-cifrova_gramotnist_naselenna_ukraini_2019_compressed.pdf

Mishchenko, V. I., \& Mishchenko, S. V. (2018). Marketynh tsyfrovykh innovatsiy na rynku bankivskykh posluh [Marketing of digital innovations in the market of banking services]. Finansovyy prostir - Financial space, vol. 1(29), pp. 75-79. Available at: http://dspace.ubs.edu.ua/jspui/bitstream/123456789/1008/1/Mishchenko_ Marketing_of_digital.pdf

Moore, G. A. (2014). Crossing the Chasm: Marketing and Selling Disruptive Products to Mainstream Customers. 3rd Edition. Harper Business.

Morozko, N. I., \& Didenko, V. Yu. (2017). Osnovnyye trendy razvitiya industrii finansovykh tekhnologiy: monografiya [The main trends in the development of the financial technology industry: monograph]. Moskva: RUSAYNS.

Statista (2020). Number of Fintech startups worldwide from 2018 to 2020, by region. Available at: https://www.statista.com/statistics/893954/number-fintech-startups-by-region

Pochenchuk, H. M. (2018). FinTech v strukturi finansovoyi systemy [FinTech in the structure of the financial system]. Hlobalni ta natsionalni problemy ekonomiky - Global and national problems of economy, vol. 21, pp. 49-55. Available at: http://global-national.in.ua/archive/21-2018/11.pdf

Rogers, E. (2003). Diffusion of Innovations. 5th ed. New York: Free Press.

Schueffel, P. (2016). Taming the Beast: A Scientific Definition of Fintech. Journal of Innovation Management, vol. 4, pp. 32-54. Available at: https://journalsojs3.fe.up.pt/index.php/jim/article/view/2183-0606_004.004_ 0004/262; doi:https://doi.org/10.24840/2183-0606_004.004_0004

Tarasyuk, M. V., \& Koshcheev O. O. (2017). Innovatsiyi v hlobalniy tsyfroviy sferi: otsinka transformatsiy [Innovations in the global digital sphere: assessment of transformations]. Aktualni problemy mizhnarodnykh vidnosyn - Actual problems of international relations, vol. 131, pp. 94-110. Available at: http://journals.iir.kiev.ua/ index.php/apmv/article/download/3167/2842

Teigland, R., Ingram Bogusz, C., Wesley-James, N., \& Kallstrand, C. (2015). Stockholm FinTech: An overview of the FinTech sector in the greater Stockholm Region. Available at: https://www.researchgate.net/publication/279052226 Stockholm_FinTech_An_overview_of_the_FinTech_sector_in_the_greater_Stockholm_Region

The USAID Financial Sector Transformation Project (2019). Financial Literacy, Financial Inclusion and Financial Well-Being in Ukraine. Survey Report. Available at: http://www.fst-ua.info/wp-content/uploads/2019/06/ Financial-Literacy-Survey-Report_June2019_en.pdf

The USAID Financial Sector Transformation Project (2019). Ukrainian FinTech and Banks Survey - 2019. Available at: http://www.fst-ua.info/wp-content/uploads/2019/12/FinTech-Survey-Report_ENG-12-12-2019.pdf

Trunin, P., Kiyutsevskaya, A., Narkevich, S., Inozemtsev, E., \& Hudko, E. (2019). Kompleksnyy analiz razvitiya mirovogo rynka Finansovykh tekhnologiy (fintekh) [Comprehensive Analysis of the Development of the Global Financial TechnologyMarket (Fintech)].Available at: https://ssrn.com/abstract=3360922; doi: http://dx.doi.org/ $10.2139 /$ ssrn.3360922

Ukrainian Association of Fintech and Innovative Companies (2019). The Ukrainian Fintech Catalog - 2019. Available at: https://map.fintechua.org

International Institute for Management Development (2019). World Digital Competitiveness Ranking - 2019. Available at: https://www.imd.org/globalassets/wcc/docs/release-2019/digital/imd-world-digital-competitivenessrankings-2019.pdf

Deloitte (2017). Fintech by the numbers. Incumbents, startups, investors adapt to maturing ecosystem. Available at: https://www2.deloitte.com/content/dam/Deloitte/tr/Documents/financial-services/dcfs-fintech-by-the-numbers.pdf 